\title{
Delirium During Electrolyte Imbalance On Craniotomy Post-Surgery Patients
}

\author{
Diah Retno Wulan ${ }^{1}$, Sri Siti Khadijah ${ }^{2}$ \\ \{wulandyahretno@gmail.com ${ }^{1 *}$, srisitikhadijah25@gmail.com $^{2}$ \}
}

${ }^{12}$ Faculty of Nursing \& Health Sciences, University of Muhammadiyah Banjarmasin, Indonesia

*wulandyahretno@gmail.com

\begin{abstract}
After surgery, patient with craniotomy tent to have electrolyte imbalances because of electrolyte and osmotic disruption due to neuroendocrine center disorder. Unfortunately, it imbalances lead to agitation and restlessness that called delirium or acute confusion state. Delirium have high prevalence among post-craniotomy patients and be serious condition that have relation with prolonged length of stay, increasing of cost, functional recovery delay, increasing of nursing care, and increasing of mortality up to 10 times. The purpose of this study was to determine the correlation of electrolyte status with delirium occurrence on postoperative patient of craniotomy. This research is an observational correlation study with cross-sectional approach. It was done in RSUD Ulin Banjarmasin on postoperative patients of craniotomy in ICU from May until June 2018. The result of statistical test of alternative chisquare (Fisher exact) showed that there was significant correlation between electrolyte imbalances ( $p$ value 0,001 ) with delirium occurrence on postoperative patients of craniotomy. This study is a pathophysiology knowledge and evidence that can use to develop delirium-nursing management, especially on craniotomy patients.
\end{abstract}

Keywords: craniotomy, delirium, electrolyte imbalance

\section{Introduction}

Delirium was originally used in medical to describe mental disorders during fever or head injury, then developed into a broader understanding, including the terms "acute confusion status", and "acute brain syndrome". Over time, the term delirium develops to explain an acute, reversible, fluctuating and arising in certain medical conditions [5]. This is also was revealed by the previous study that delirium is an acute or sub-acute syndrome, usually reversible, cognitive impairment, and behavior. The main manifestation of delirium is a quickly change of consciousness and cognitive in a short time. Other manifestations include lack of attention, impaired perception, thinking, memory, psychomotor, emotions, and sleepwake patterns [4], [1].

Delirium is a syndrome with a variety of appearance symptoms. Patients with hyperactivity delirium, delirious with aggressive, restless and hallucinatory behavior, occur in only about $5 \%-22 \%$ of the total patients, but the majority of critical patients that occur are hypoactive delirium or a mixture of both which usually fluctuates from hyperactivity to hypoactive. Patients with hypoactive delirium are usually often undetectable and have a higher risk of death [11]. The average patient admitted to the ICU has 11 or more risk factors for delirium that are divided into predisposing factors and precipitation factors. Predisposing factors are related to patient characteristics and precipitation factors associated with acute illness of patients and management in the ICU itself [3].

Most opinions state that the causes of delirium are cholinergic activity decreasing that causes neurotransmitters, and a decrease of cholinergic activity itself has many underlying 
factors [5]. Different pathophysiological mechanisms result in different influences and prognoses in the state of the delirium. The circumstances that cause brain neurotransmitter disorders are often found on postoperative craniotomy patients actually electrolyte imbalance that very important to regulate fluid balance in the body. Increased level of sodium and potassium in the blood cause the transfer of fluid into brain cells in which causes brainswelling, disruption of the brain membrane and brain volume in which triggers delirium [1].

A meta-analysis states that the mortality rate due to the incidence of delirium in intensive care is $95 \%$ [8]. In Indonesia, the exact prevalence of delirium treated in intensive space has not been obtained and proves that the detection of delirium, especially surgery for craniotomy is less noticed, whereas delirium is one of the most common complications in critical nursing. Delirium has a high incidence in patients with critical illness and a serious disorder associated with prolonged length of stay, higher costs, delayed functional recovery, increasing care needs of health worker, increasing mortality and morbidity rates more than 10 times [5].

\section{Method}

This study was an observational correlation with a cross-sectional approach to 30 respondents of postoperative craniotomy patients 24 hours after surgery. Data collected from May until June 2018 in ICU of Ulin General Hospital Banjarmasin. Delirium assessed using a modified CAM-ICU observation sheet from the Confusion Assessment Method (CAM) with an evaluation of four features, that are acute mental status changing or fluctuating, attention decreasing, impaired level of awareness and disorganization of the mind. Positive delirium respondents experienced features one and two that accompanied by one of feature three or four. Electrolyte status data was seen from the medical records of respondents' laboratory examinations. Respondents were considered to have electrolyte disturbances if the electrolyte value was outside the normal range, that is sodium 135 to $146 \mathrm{mmol} / \mathrm{L}$, potassium 3.4 to 5.4 $\mathrm{mmol} / \mathrm{L}$ and chloride 95 to $100 \mathrm{mmol} / \mathrm{L}$.

\section{Result}

Bivariate analysis has elaborated the results of statistical test between the independent variable and the dependent variable for electrolyte status with the occurrence of delirium on postoperative craniotomy patients. The Chi Square Alternative test, Fisher Exact, found an association between electrolyte statuses with the occurrence of delirium on postoperative craniotomy patients.

Table 1. Electrolyte Status Distribution of Respondents

\begin{tabular}{lccc}
\hline & Electrolyte Status & n & \% \\
\hline Hypercloremia & 20 & 66,7 \\
\hline Hyponatremia & $\Sigma$ & 5 & 16,7 \\
\hline Normal & 5 & 16,7 \\
\hline
\end{tabular}


Table 2. Delirium Incidents of Respondents

\begin{tabular}{lccc}
\hline & Delirium & n & \% \\
\hline Positive & & 21 & 70 \\
\hline Negative & & 9 & 3 \\
\hline & $\Sigma$ & 30 & 100 \\
\hline
\end{tabular}

Table 1 shows an overview of respondent's characteristic based on electrolyte state. Most of the respondents $(83,4 \%)$ had electrolyte imbalance both hypercloremia $(66,7 \%)$ and hyponatremia $(16,7 \%)$, Furthermore they had a normal electrolyte state $(16,7 \%)$. Table 2 shows Table 1 shows an overview of respondent's characteristic based on delirium state. Most of the respondents were positive had delirium state $(70 \%)$ and other than that they were negative $(3 \%)$.

Table 3. Relationship Between Electrolyte Status and Delirium Incidents

\begin{tabular}{|c|c|c|c|c|c|c|}
\hline \multirow{3}{*}{ Electrolyte Status } & \multicolumn{4}{|c|}{ Delirium Incidents } & \multirow{3}{*}{$\Sigma$} & \multirow{3}{*}{$\%$} \\
\hline & \multicolumn{2}{|c|}{ Positive } & \multicolumn{2}{|c|}{ Negative } & & \\
\hline & $\mathrm{n}$ & $\%$ & $\mathrm{n}$ & $\%$ & & \\
\hline Normal & 0 & 0 & 5 & 100 & 5 & 100 \\
\hline Abnormal & 21 & 84 & 4 & 16 & 25 & 100 \\
\hline$\Sigma$ & 21 & 70 & 9 & 30 & 30 & 100 \\
\hline \multicolumn{7}{|c|}{ Chi Square (Fisher Exact) $\rho$ value $=0,001$} \\
\hline
\end{tabular}

Table 3 is a result of the cross tabulation that showed $84 \%$ of respondents with abnormal electrolyte state had delirium experience. Furthermore, bivariate analysis using Fisher Exact between electrolyte state and delirium incident on respondents obtained $0,001 \rho$ value. It means there is a significant relationship between electrolyte state and delirium incident.

\section{Discussion}

Based on bivariate statistical tests showed that $p$ value $0.001(<0.05)$ means that there is a significant relationship between electrolyte status and the incidence of delirium in patients postoperative craniotomy in ICU of Ulin Hospital Banjarmasin. The above results show that the patients who experienced abnormal electrolyte status tent to have delirium experience. According to the previous study revealed delirium is a complex, multifactorial phenomenon, and affects various parts of the central nervous system. The latest hypothesis shows that cholinergic pathway deficiency combined with dopaminergic hyperactivity can be one of the factors causing delirium [5].

Although there are several types of electrolyte disorders, sodium imbalances such as hyponatremia and hyperchloremia are common on postoperative patients that tend to cause one of the disorders of brain dysfunction, namely delirium. Electrolytes are electrically charged minerals stored inside and outside the body's cells, working together with water to maintain homeostasis, or achieving an important balance to maintain life. Most metabolic processes require and are affected by electrolytes. Electrolytes are molecules that break into electrically charged particles (ions). It consists of cations (+) and anions (-) and are measured 
by their capacity in milliequivalents $(\mathrm{mEq})$. Electrolyte balance occurs when the total number of cations (+) always equals the total number of anions (-) and must be maintained [10]. Therefore, abnormal electrolytes can cause many disorders.

Electrolyte abnormality like hyponatremia is very often found in the scope of neurosurgery and neuro-ICU. The most often neurological pathology are subarachnoid bleeding, cerebrovascular attacks, head tumors, and head injury those cause hyponatremia due to syndrome of inappropriate secretion of anti-diuretic hormone (SIADH) or cerebral salt wasting syndrome (CSWS), each of which results in release ADH (antidiuretic hormone) or natriuretic peptide from the brain as a response to an injury [9]. Impaired of electrolytes will affect the brain's neurotransmitter process which causes disturbed electricity delivery processes. So that can disturb the function of brain as a center organ regulation and result in neurological disorders.

In addition to hyponatremia, in this study also found the occurrence of hyperchloremia or excessive level of chloride in the blood. Hyperchloremia can occur due to the administration of fluid therapy for postoperative patients that usually used fluids that easily penetrate the blood brain barrier. Hyperchloraemia after postoperative craniotomy occurs as a result of fluid post referral surgery that used a lot of fluids with osmolality that resembles the blood brain barrier $(0.9 \% \mathrm{NaCl})$ to avoid edema in the brain. So that in patients after surgery, craniotomy is often found in hyperchloremic acidosis with symptoms of agitation and tachycardia. Chloride is one part of electrolyte that dominates CES (Extracellular Fluid) and part of sodium that plays a role in neuro-electricity delivering process, thus affecting neurotransmitters and synapses between neurons. Even though Electrolyte linkages with delirium have not been known, but increased level of sodium or potassium in the blood cause fluid transfer into brain cells which causes brain swelling, impaired of brain membranes and brain cells volume, disruption of potential cell actions transmission. It condition result in delirium state [6], [7], [2].

\section{Conclusion}

Based on the discussion above it can be concluded that electrolyte/abnormal electrolyte disturbances are common in postoperative patients, especially neurosurgery/craniotomy. This electrolyte abnormality can disrupt the brain's transmitter process and trigger brain damage with symptom that called delirium. Based on previous theories that stated delirium have an high impact to mortality, health worker should be aware and make immediate decision to manage post-operative craniotomy patients. The important step is developing delirium management with integrated electrolyte imbalances assessment and appropriate intervention.

\section{Acknowledgement}

Be thankful for University of Muhammadiyah Banjarmasin, Ulin General Hospital and all of peers that allow and support this study.

\section{References}

[1] Adiwinata, R., Oktaliansah, E., \& Maskoen, T.T.: Angka Kejadian Delirium dan Faktor Risiko di Intensive Care Unit Rumah Sakit Dr. Hasan Sadikin Bandung. Jurnal Anestesi Perioperatif. Vol. 4. pp. 36-41. (2016) 
[2] Ali, Z., Prabhakar, H.: Fluid Management during Neurosurgical Procedures. Journal of Neuroanaesthesiology and Critical Care. Vol 3. pp. 35-40. (2016)

[3] Brummel \& Girard : Preventing Delirium in The Intensive Care Unit. NIH Publisher Access. Vol 29. pp. 51- 65. (2013).

[4] Horacek, R., Krnacova, B., Prasko, J., Latalova, K.: Delirium As A Complication of The Surgical Intensive Care. Dovepress. pp. 2425-2434. (2016)

[5] Luman, A.: Delirium Syndrome. (Department of Medicine. Fakultas Kedokteran Universitas Sumatra Utara, Medan.) Vol 42. pp. 744-748. (2015)

[6] Martinus, F., Fuadi, I., Bisri, T.: Perbandingan Osmolaritas, Kadar Natrium dan Klorida Plasma Setelah Pemberian NaCl-RL (3:1) dengan Ringerfundin pada Pasien Tumor Otak. Jurnal Neuroanestesi Indonesia. Vol 3. pp. 1-7. (2014)

[7] Rohmawanur, T.T., Indriasari, Redjeki, I.S.: Risk Ratio Kejadian Pada Pasien dengan Faktor Risiko yang dinilai dengan Confussion Assessment Method of Intensive Care Unit (CAM-ICU) di Perawatan Ruangan Intensif Rumah Sakit Dr. Hasan Sadikin Bandung. Anesthesia \& Clinical care. Vol 33. pp. 206-212. (2015)

[8] Skwarecki, B.: Artikel. Delirium in ICU Patient Linked to Mortality, Longer Stays (internet). Available in <https://www.medscape.com/viewarticle/845901> (accessed 16 Desember 2017). (2015)

[9] Syah, B.I.A., Gaus, S., Rahardjo, S.: Manajemen Cairan dan Elektrolit Pada Pasien Cedera Kepala. Journal Neuroanestesi Indonesia. Vol 5. Pp. 197-209. (2016)

[10] Syaifuddin. Ilmu Biomedik Dasar Untuk Mahasiswa Keperawatan (Jakarta: Salemba Medika). (2016).

[11] Wulan, D.R.: Analisis Faktor yang Berhubungan dengan Kejadian Delirium Pada Pasien Pascaoperasi Kraniotomi di Intensive Care Unit (ICU) RSUD Ulin Banjarmasin. (Tesis Program S2 Ilmu Keperawatan Universitas Muhammadiyah Banjarmasin). (2017) 